SJ Quinney College of Law, University of Utah Utah Law Digital Commons

Utah Law Faculty Scholarship

Utah Law Scholarship

$1-26-2017$

\title{
Zero Sum Games in Pollution Control: The Games We Create versus the Games We Discover
}

Robin Kundis Craig

S.J. Quinney College of Law, University of Utah, robin.craig@law.utah.edu

Follow this and additional works at: http://dc.law.utah.edu/scholarship

Part of the Law Commons

\section{Recommended Citation}

Craig, Robin Kundis, "Zero Sum Games in Pollution Control: The Games We Create versus the Games We Discover" (2017). Utah Law Faculty Scholarship. 12.

http://dc.law.utah.edu/scholarship/12

This Article is brought to you for free and open access by the Utah Law Scholarship at Utah Law Digital Commons. It has been accepted for inclusion in Utah Law Faculty Scholarship by an authorized administrator of Utah Law Digital Commons. For more information, please contact

valeri.craigle@law.utah.edu. 


\title{
Zero Sum Games in Pollution Control: The Games We Create versus the Games We Discover
}

\author{
Robin Kundis Craig ${ }^{*}$
}

\begin{abstract}
Environmental pollution lands us in zero-sum games. ${ }^{1}$ The more interesting question is: Do we discover these games? Or do we invent them? In other words, are there hard environmental limits on how much anthropogenic pollution natural systems can absorb, which we eventually discover? Or do we create zero-sum games for pollution purely as a result of our own goals for both ecosystems and social-ecological systems (SESs, a recognition that human societies are both part of and depend upon functioning ecosystems)? In fact, we do both, and the intersection of the two in a climate change era is worth examination.
\end{abstract}

There is no doubt that natural systems respond to, and can be altered by, human pollution, and at all sorts of scales. The emerging discipline of resilience theory posits that ecosystems can exist in alternative stable states and that they transform from one state to another by crossing an ecological threshold. ${ }^{2}$ While resilience theory imposes no normative value on these alternative states, ${ }^{3}$ as a pragmatic matter humans tend to find one state more desirable than the others. Relatedly, and importantly, crossing an ecological threshold in one direction is often easier than reversing the process. Thus, when ecosystems are in humandesired states, keeping that system from crossing an ecological threshold in the first place is often far less costly than trying to restore the ecosystem afterwards. As a result, identifying ecological thresholds and the most desirable of alternative states can help to inform legal and policy goals.

Pollution often prompts one of the most common ecological transformations-namely, the eutrophication of waterbodies as a result of excess nutrient (nitrogen and phosphorus)

\footnotetext{
* James I. Farr Presidential Endowed Professor of Law, University of Utah S.J. Quinney College of Law, Salt Lake City, UT. The author may be reached at robin.craig@law.utah.edu.

${ }^{1}$ John von Neumann and Oskar Morgenstern came up with the concept of zero-sum games as part of their invention of game theory. ThOMAS S. FERGUSON, GAME TheORY II-4 (UCLA Department of Mathematics 2011). In game theory, a zero-sum game is one in which no wealth is created or destroyed; one person's gain must result in another person's (or persons') loss to the same amount or degree. Id. More colloquially, zero-sum games can be viewed as problems where there is a single unchanging "pie" of resources and several people are seeking to increase the size of their slice; they can only do so by decreasing the amount of pie available to everyone else.

${ }^{2}$ Lance H. Gunderson \& C. S. Holling, Panarchy: Understanding Transformations in Human and NATURAL SYSTEMS 34 (Washington, DC: Island Press, 2002).

3 Brian Walker \& David Salt, Resilience Thinking: Sustaining Ecosystems and People in a Changing WORLD 7-9 (2006).
} 
pollution. ${ }^{4}$ Eutrophication transforms aquatic ecosystems from clear, oxygenated, and often cooler waters that can support a variety of plant and animal species to ecosystems dominated by algae, hypoxic (low-oxygen) or anoxic (no-oxygen) warmer water, with greatly reduced biodiversity. ${ }^{5}$ Moreover, once an aquatic system has eutrophicated, restoring it to its previous and often more productive ecosystem state can be very difficult. ${ }^{6}$

Thus, eutrophication thresholds could be considered to define a zero-sum pollution game that we've discovered. Specifically, if we are pursuing a normative goal of keeping the aquatic system in its non-eutrophic state (which is, in fact, what people usually want), the aquatic system's capacity to absorb nutrients without transforming defines a limited pollution "pie" for achieving that governance goal. Assuming that polluters have reached this capacity, no polluter can increase its nutrient pollution without either another polluter having to reduce its pollution or the system transforming.

The entire planet may also be limited in how much pollution of various sorts it can absorb without transforming into-well, something radically different than the planet we and our hominid relatives have enjoyed for the last 12,000 years during the Holocene. In Big World, Small Planet: Abundance Within Planetary Boundaries, Johan Rockström and Mattias Klum describe the Planetary Boundaries Project. ${ }^{7}$ This project is the effort of a team of scientists to identify key planetary boundaries - parameters that, if exceeded, risk transforming the entire Earth and its ecosystems. ${ }^{8}$ In its 2014 update to the original 2009 research, the team identified nine such planetary boundaries. ${ }^{9}$ Three of these- "the Big Three"-reflect "processes with sharply defined global thresholds" that are "hard-wired into the Earth system and cannot be shifted by human actions," processes that "are capable of sharp shifts from one state to another, with direct implications for the entire planet." ${ }^{10}$ These Big Three planetary boundaries are climate change, stratospheric ozone depletion, and ocean acidification. ${ }^{11}$ Notably, the planet is at risk of crossing all three of these boundaries because of human pollutionrespectively, greenhouse gases, ozone-depleting chemicals, and anthropogenic carbon

4 National Oceanic \& Atmospheric Administration, Ocean Service Education, Nutrient Pollution-Eutrophication, http://oceanservice.noaa.gov/education/kits/estuaries/media/supp_estuar09b_eutro.html (as revised Mar. 25, 2008, and viewed Jan. 25, 2017).

${ }^{5}$ Id.

6 Stpehen R. Carpenter, Eutrophication of aquatic systems: Bistability and soil phosphorus, 102:29 PNAS (Proceedings of the National Academy of Sciences) 10002, 10005 (July 19, 2005), available at http://www.pnas.org/content/102/29/10002.full.pdf.

7 Johan Rockström \& Mattias Klum, Big World, Small Planet: Abundance Within Planetary BOUNDARIES 64-77 (Yale University Press 2015).

${ }^{8}$ Id. at 64 .

${ }^{9}$ Id. at 65 fig. 2.1 .

${ }^{10} / d$. at 69.

${ }^{11} / d$. 
dioxide. ${ }^{12}$ In addition, the risks of exceeding three other planetary boundaries-biochemical flows (nutrient cycles), atmospheric aerosol loading, and novel entities (toxics)-are directly related to anthropogenic pollution, with the scientists concluding in 2014 that we're already at high risk of exceeding the phosphorus and nitrogen limits. ${ }^{13}$ (The other three planetary boundaries are biodiversity, freshwater consumption, and land use change. ${ }^{14}$ )

One way of interpreting the results of the Planetary Boundaries Project, therefore, is that we've discovered that much pollution is, ultimately, a zero-sum game at the planetary scale-at least if we want to avoid transforming the Earth into a very different state of being, one that is probably far less hospitable to the current forms of life existing here (including us). There's decent evidence that if people and governments believe and appreciate the systemic risks from pollution, they (eventually) will act (at least so far as the capacity to act exists) to reduce those risks, particularly if they can do so relatively cheaply and easily. For example, scientists discovered a recurring hole in the atmospheric ozone layer in 1984 and published their results in Nature in May $1985 .{ }^{15}$ By September 1987, the world's nations had agreed to the Montreal Protocol on Substances that Deplete the Ozone Layer, a treaty that phased out the production and consumption of many ozone-depleting chemicals. ${ }^{16}$ In June 2016, scientists reported that the ozone hole is starting to "heal." ${ }^{17}$ Thus, stratospheric ozone depletion is one pollution-related planetary boundary from which the world appears to be retreating.

However, not all zero-sum pollution games result from "discovered" natural limits of ecological thresholds and planetary boundaries. Instead, some of these games reflect human regulatory choices about the environmental quality that we desire. For example, the United States and Canada noticed acid rain problems in the 1960 s and 1970s. ${ }^{18}$ Acid rain was clearly affecting ecosystems such as maple forests and lakes in both countries; ${ }^{19}$ whether it was driving them toward ecological thresholds and transformations is a far more open question. Nevertheless, in 1990, Congress amended the Clean Air Act to impose a comprehensive "capand-trade" program for sulfur dioxide and nitrogen oxides, effectively creating a regulatory zero-sum game for emissions of these pollutants. ${ }^{20}$ In 1991, Canada and the United States

${ }^{12}$ Id. at 65 fig. 2.1.

${ }^{13} / d$

${ }^{14} / d$.

15 J.C. Farman, B.G. Gardiner, \& J.D. Shanklin, Large losses of total ozone in Antarctica reveal seasonal $\mathrm{ClO}_{x} / \mathrm{NO}_{x}$ interaction, 315 NATURE 207-10 (16 May 1985).

16 United Nations, International Day for the Preservation of the Ozone Layer, http://www.un.org/en/events/ozoneday/background.shtml (as viewed Jan. 25, 2017).

17 Aaron Sidder, "Remember the Ozone Hole? Now There's Proof that It's Healing," National Geographic, news.nationalgeographic.com/2016/06/antarctic-ozone-hole-healing-fingerprints/ (June 30, 2016).

18 Gene E. Likens \& Richard T. Holmes, The Discovery of Acid Rain, http://blog.yupnet.org/2016/05/04/discovery-acid-rain/ (May 4, 2016).

${ }^{19} / d$.

${ }^{20}$ Pub. L. No. 101-549, Title IV, 104 Stat. 2584 (Nov. 15, 1990). 
entered into a treaty to address acid rain, effectively extending the cap-and-trade concept across national boundaries. ${ }^{21}$ Cap-and-trade programs are regulatory zero-sum games: The "cap" sets the total amount of pollution allowed, while the trading reflects the fact that one polluter's need to emit beyond its assigned allowance must be matched by another polluter's (or polluters') willingness to reduce its (their) emissions below those allowances. ${ }^{22}$

Water pollution in the United States is also subject to regulatory zero-sum games, in the form of the Clean Water Act's Total Maximum Daily Load (TMDL) requirements. ${ }^{23}$ The TMDL is the total amount of a pollutant that a waterbody can take in on a daily basis without violating its state-defined water quality standards. ${ }^{24}$ These water quality standards reflect both the uses of the waterbody that were present in 1972 and the state's as-yet-unattained use goals for that waterbody, with a general national goal that all waterbodies should be fishable and swimmable. ${ }^{25}$ Thus, with few exceptions, states do not set water quality standards to reflect actual ecological thresholds but rather the uses that exist or can be restored within the current system state. ${ }^{26}$ As such, water quality standards and the TMDLs that result from them are not "discovered" zero-sum pollution games. Instead, TMDLs, like cap-and-trade programs, are regulatory zero-sum games created to achieve human-defined pollution reduction goals. The total amount of pollutant allowed under the TMDL is divided among natural background sources and human sources of the pollutant, requiring human sources that exceed their assigned allowance to reduce their pollutant contribution levels. ${ }^{27}$ The U.S. Environmental Protection Agency and the states are also beginning to experiment with water quality trading for certain pollutants, ${ }^{28}$ providing a market-based method for polluters to adjust their individual pollution levels under the TMDL-but the market only works because the TMDL creates a legal zero-sum pollution game.

21 Environment \& Climate Change Canada, Canada-United States Air Quality Agreement, https://www.ec.gc.ca/air/default.asp?lang=En\&n=83930AC3-1 (as viewed Jan. 26, 2017). The treaty itself is available at: http://www.ijc.org/rel/agree/air.html.

${ }^{22}$ Rosaly Byrd, "An Introduction to Cap-and-Trade Systems Around the World," The Huffington Post, http://www.huffingtonpost.com/rosaly-byrd/an-introduction-to-carbon-cap-andtrade_b_6737660.html (Feb. 24, 2015).

${ }^{23} 33$ U.S.C. $\$ 1313(d)$.

24 U.S. Environmental Protection Agency, Implementing Clean Water Act Section 303(d): Impaired Waters and Total Maximum Daily Loads (TMDLs), https://www.epa.gov/tmdl (as updated Set. 21, 2016, and viewed Jan. 26, 2017).

${ }^{25} 33$ U.S.C. § 1313(c); 40 C.F.R. § 131.3(i).

26 See U.S. Environmental Protection Agency, What Are Water Quality Standards?, https://www.epa.gov/standards-water-body-health/what-are-water-quality-standards (as updated Nov. 3, 2016, and viewed Jan. 26, 2017) (describing how states set water quality standards).

2740 C.F.R. $\S 130.2(i)$.

28 U.S. Environmental Protection Agency, Frequently Asked Questions About Water Quality Trading, https://www.epa.gov/npdes/frequently-asked-questions-about-water-quality-trading (as updated July 8, 2016), and viewed Jan. 26, 2017). 
In the absence of clearly stated environmental quality goals-National Ambient Air Quality Standards under the Clean Air Act, ${ }^{29}$ water quality standards under the Clean Water $\mathrm{Act}^{30}$-and a regulatory program for achieving them, humans tend to operate as if pollution is not a zero-sum game right up until the point where they push a system across a threshold or boundary. In this sense, ambient environmental quality goals and regulatory zero-sum gamesthe zero-sum pollution games that we invent-can keep us from having to discover that pollution is a zero-sum game at a larger scale (at least to the extent that we want to avoid ecosystem and planetary transformations). Moreover, given that it's often hard to fight our way back when we hit those limits - it has taken almost three decades for the ozone hole to begin to respond to the Montreal Protocol, and many eutrophic waterbodies remain transformedthe concepts of ecological thresholds and planetary boundaries suggest that defining more regulatory zero-sum pollution games might help us to define and stay within safe operating spaces for human activity (assuming our science is good enough to identify those boundaries and thresholds accurately).

Of course, the elephant in the room is climate change. Is climate change a zero-sum pollution game? The many debates over the "proper" target for atmospheric greenhouse gas concentrations ( 350 parts per million carbon dioxide equivalents, or 400 , or 450 ) suggests that both climate change scientists and climate change activists perceive climate change to be zero sum. ${ }^{31}$ Moreover, the politics of climate change mitigation negotiations are clearly driven by perceptions that parceling out emissions reduction commitments and total emissions limits creates winners and losers-people who get more or less than their fair shares of a limited emissions "pie." 32

But climate change, as usual, is more complex than just the mitigation zero-sum game. The Planetary Boundaries Project scientists consider climate one of two "core" boundaries (biodiversity is the other), because the climate system has "a decisive role, on [its] own, in determining the outcome of the planetary state." ${ }^{\prime 3}$ With respect to pollution, if the world refuses to acknowledge and play the climate change mitigation zero-sum game, the parameters

${ }^{29} 42$ U.S.C. $\S 7409 /$
${ }^{30} 33$ U.S.C. $\S 1313$ (c).

31 Arthur Neslen, "Carbon dioxide levels in atmosphere forecast to shatter milestone," The Guardian, http://www.huffingtonpost.com/rosaly-byrd/an-introduction-to-carbon-cap-andtrade_b_6737660.html (13 June 2016) (discussing the 400 ppm and 450 ppm thresholds, noting that the Intergovernmental Panel on Climate Change has settled on the latter); 350.org, The Science, https://350.org/about/science/ (as viewed Jan. 25, 2017) (document its and Dr. James Hansen's commitment to $350 \mathrm{ppm}$ as a goal).

32 Most famously, the Kyoto Protocol to the United Nations Framework Convention on Climate Change sought to impose greenhouse gas emissions reduction targets on developed nations. United Nations, United Nations Framework Convention on Climate Change: Kyoto Protocol, http://unfccc.int/kyoto_protocol/items/2830.php (as viewed Jan. 25, 2017).

${ }^{33}$ Rockström \& Klum, supra note 7 , at 71. 
of many of the other zero-sum pollution games are likely to change on us, calling into question the continued viability of the zero-sum pollution games we've created. Many forms of pollution are sensitive to temperature, ${ }^{34}$ for example, and climate change may make many of the environmental quality goals that bound regulatory zero-sum games impossible to achieve-for example, ground-level ozone goals, ${ }^{35}$ water temperature goals, ${ }^{36}$ ocean $\mathrm{pH}$ goals. ${ }^{37}$ Thus, climate change impacts push many ecosystems, and perhaps the planet as a whole, toward transformation, it's important to remember that the zero-sum pollution games we invent are, ultimately, depending on the zero-sum pollution games we discover.

${ }^{34}$ Daniel J. Jacob \& Darrell A. Winner, Effect of climate change on air quality, 43 ATMOSPHERIC ENVIRONMENT 51, 54-55 (2009).

35 Id. at 60.

${ }^{36}$ Robin Kundis Craig, Climate Change Comes to the Clean Water Act: Now What?, 1 WASH. \& LEE J. Energy, Climate, \& Envt. 9, 12, 19-20 (Spring 2010).

${ }^{37}$ Robin Kundis Craig, Dealing with Ocean Acidification: The Problem, the Clean Water Act, and State and Regional Approaches, 90 Wash. L. Rev. 1583, 1612-1627 (Dec. 2015). 